\title{
Factor Analysis of Railway Passenger Transport Demand in Eastern China
}

\author{
Feina Zhu \\ Shanghai University \\ Shanghai China \\ 331022743@qq.com
}

\begin{abstract}
The railway is the major artery of national economic development. At present, the demand for railway passenger transportation presents the characteristics of multistructure, multi-level, and multi-segmented markets. To achieve the coordinated development of railway enterprises and the economy is a major challenge. In order to construct a railway passenger transport demand system. This paper uses the method of factor analysis and puts forward to three common factors to build up the comprehensive scoring model in 9 indicators. It shows that the demand for railway passenger transport in various provinces in the eas tern part of China is different. The factors influencing the demand for railway passenger transport in all provinces are also different, among which Beijing and Shanghai are the highest, and Hebei and Hainan are lower. China's railway construction needs to pay attention to the gaps be tween dis tricts.
\end{abstract}

Keywords-railway passenger transport demand; factor analysis; comprehensive analysis;

\section{INTRODUCTION}

Under the condition that the cost of road transports improved, railway, as the important infrastructure of a country, has been paid more and more attention. It creates an excellent environment for the development of railway. In 2013, the railway industry started to separate government functions from enterprise management. From then on, China railway Corporation undertook the responsibility of the enterprises and self-financing. This meant that the construction of railway should adapt to the market and faced huge challenges.

\section{LITERATURE REVIEW}

Cui Yanping, li Yan, Cheng Wenyi and Liu Bing (2014) analyzed the significance of external development environment of railway passenger transport and passenger demand characteristics for the development of railway passenger transport. [1] The demand characteristics of railway passenger transport market were proposed. That high-end passenger demand would grow rapidly and the requirement of speed would be higher. Passenger transport demand would be diversified and personalized [2] .

Tian Fei (2012) established a regression model for the intercity railway passenger transport demand, population, GDP and the correlation of regional passenger demand. From the perspective of passenger flow change caused by the difference of income distribution, he revised the population dependent variable and GDP dependent variable to optimize the total passenger demand forecast of intercity railway [3]

Zhang Nian (2014) calculated the comprehensive score and ranking of railway freight demand in the central and western provinces. Research shows that the central and western regions in China railway freight transportation demand gap is large and the main influence factors are different [3].

\section{THEORY OVERVIEW}

\section{A. Concepts and characteristics of passenger demand}

Passenger demand: the number of people who are willing and able to move from $\mathrm{A}$ to $\mathrm{B}$ in a given period of time for each possible price.

There are four factors that constitute passenger flow: the number of flow, the direction of flow, the distance of flow and the period of flow.

Railway demand includes two aspects: passenger demand and freight demand.

This paper analyzed the passenger demand of railway.

\section{B. Characteristics of railway passenger demand}

At present and in the future, China's railway passenger demand has the following characteristics:

- High-end passenger demand will grow rapidly. With the rapid development of economy, after solving basic life need, demand will change from the pursuit of material consumption to the pursuit of spirit consumption and service consumption. Therefore, the related consumer passenger demand also increases quickly. So the percentage of consumer passenger transportation demand in the passenger transport demand will continue to improve.

- The demand for fast passenger transportation is getting higher and higher. The time value of passengers is the opportunity cost of time consuming in the passenger travel. With the development of economic society and the improvement of income, the time value of passenger keeps increasing and the travel time will become the important measure among the mode of transportation.

- Passenger transport demand presents the trend of diversification and individuation. The gap between 
China's regional economic development level is large so that people's income and regional culture is differently.

- Therefore, the diversity of travel modes rare required by tourists, which requires diversified, multi-level and multi-directional modes of travel and products.

- Demand to form the overall advantage of the travel industry chain. From the perspective of the products provided, as the railway passenger transport industry value chain extends, the railway enterprises provide passengers not only the travel service, but also the re but also the related products in the industrial value chain.

\section{INDEX SYSTEM.}

Combined with the principle of index system construction, this paper analyzes the characteristics of railway passenger transport demand and the factors that affect its development, and refers to the index construction system of others. Finally deciding to construct the indicator system of railway passenger transport demand from the following three aspects.

\section{A. Macroeconomic environment}

Economic growth is the main factor affecting passenger demand. In 2015, China's gross domestic product grew by $6.7 \%$, achieving the expected target of $6.5 \%-7 \%$. It shows that China's economy is in a period of rapid development, and the rapid economic development cannot be separated from the support of transportation.

Economic growth is the main factor affecting passenger demand. In 2015, China's gross domestic product grew by $6.7 \%$, achieving the expected target of $6.5 \%-7 \%$. It shows that China's economy is in a period of rapid development, and the rapid economic development cannot be separated from the support of transportation. A series of economic activities such as business trips, various conferences, and various types of expositions require the support of transportation, and railway has become one of the important supports. Therefore, a comprehensive analysis of the demand for railway passenger transport can be conducted from the perspective of the macroeconomic environment. After adjusting the indicators, this paper finally selects three indicators, namely the per capita GDP, the level of household consumption, and the average wage of employees in urban units.

\section{B. Industrial Development Environment}

In 2015, the value added of China's primary industry increased by $3.5 \%$ year-on-year. The added value of the secondary industry increased by $6.1 \%$ year-on-year, and that of the tertiary industry increased by $8.4 \%$ year-on-year. In addition, the Fifth Plenary Session of the 17th CPC Central Committee made it clear that the "12th Five-Year Plan" period is a crucial period for building a well-to-do society in an allround way, and that it will accelerate the transformation of the mode of economic development. Building a long-term mechanism to expand domestic demand, adhere to the principle of expanding domestic demand, especially consumer demand. Promoting economic growth from the main investment and export pull to the reliance on consumption, investment, and export coordination. In particular, it is necessary to speed up the development of the service industry and promote economic growth to rely on the first, second, and third industries. This will accelerate the flow of people and goods throughout the society, and the total demand for passenger transport in the society will continue to grow, thus boosting railway passenger transport.

Therefore, this paper intends to select the first industry added value, the second industry added value and the third industry added value as indicators. Considering that the first industry is mainly related to agriculture and the demand for railway passenger transport is not relevant. So we select the added value of the secondary industry and the tertiary industry as the factors that reflect the development of the industry.

\section{Railway industry development environment}

The 2013-2017 China Railway Industry Market Forecast and Investment Strategic Planning Analysis Report shows that the total length of China's electrified railway has exceeded 51,000 kilometers in 54 years, surpassing Russia, the world's largest electrified railway, and it has risen to the top in the world.

This paper combines data from the Bureau of Statistics, and finally selects the following three indicators to reflect the development of the railway industry, the operating mileage, the number of employees in the transport industry, and the railway passenger traffic volume.

\section{Railway Passenger Transportation Demand EVALUATION AND EMPIRICAL ANALYSIS}

Based on the railway Passenger Demand Appraisal Index System constructed in the previous section, through the collection of indicator data, we conduct an empirical analysis of the railway passenger demand in the selected 8 provinces and 3 cities in the east in the method of factor analysis.

This paper selects the data of 12 regions of eastern china from China Statistical Yearbook 2016.

\section{A. Empirical analysis}

Determination of the number of factors, this paper uses SAS for factor analysis and selects factors based on the eigenvalues, as shown in Table 1.

\section{TABLE I. EIGENVALUES TABLE}

\begin{tabular}{|c|c|c|c|c|}
\hline & Eigenvalue & Difference & Proportion & Cumulative \\
\hline 1 & 4.0146 & 1.8172 & 0.5018 & 0.5018 \\
\hline 2 & 2.1974 & 0.9450 & 0.2747 & 0.7765 \\
\hline 3 & 1.2525 & 0.9660 & 0.1566 & 0.9331 \\
\hline 4 & 0.2865 & 0.1120 & 0.0358 & 0.9689 \\
\hline 5 & 0.1745 & 0.1258 & 0.0218 & 0.9907 \\
\hline 6 & 0.0486 & 0.0305 & 0.0061 & 0.9968 \\
\hline 7 & 0.0182 & 0.0105 & 0.0023 & 0.9990 \\
\hline 8 & 0.0077 & & 0.0010 & 1.0000 \\
\hline
\end{tabular}

The criterion for factor extraction is to select the number of eigenvalues greater than 1 for the correlation coefficient matrix 
to be the public factor number. From the table, we can see that there are 3 eigenvalues greater than 1 and the cumulative variance contribution rate reaches $93.31 \%$. This can be used to evaluate the overall level of railway passenger demand in the eastern region, so we should take 3 common factors.

\section{B. Build a factor load matrix}

By comparing the maximum variance method with the fourth-order rotation method, this paper concludes that the largest variance method can be used to obtain better factor classification results.

TABLE II. ROTATED FACTOR LOAD MATRIX

\begin{tabular}{|c|c|c|c|c|}
\hline & Factor1 & Factor2 & Factor3 & Factor name \\
\hline $\begin{array}{c}\text { Gross Regional } \\
\text { Product Per Capita }\end{array}$ & 0.9255 & 0.0017 & 0.0269 & \multirow{3}{*}{$\begin{array}{c}\text { Economic } \\
\text { Development and } \\
\text { Household } \\
\text { Consumption Factor }\end{array}$} \\
\hline $\begin{array}{c}\text { Per capita } \\
\text { consumption of } \\
\text { different regions }\end{array}$ & 0.9733 & 0.0662 & 0.0132 & \\
\hline $\begin{array}{l}\text { Average salary of } \\
\text { employed persons in } \\
\text { urban units (Yuan) }\end{array}$ & 0.9562 & $\begin{array}{c}- \\
0.1627\end{array}$ & 0.0107 & \\
\hline $\begin{array}{c}\text { Operating mileage } \\
(10,000 \mathrm{~km})\end{array}$ & $\begin{array}{c}- \\
0.6376 \\
\end{array}$ & 0.4000 & 0.6292 & \multirow[b]{2}{*}{$\begin{array}{c}\text { Industrial } \\
\text { Development Factor }\end{array}$} \\
\hline $\begin{array}{l}\text { Number of } \\
\text { employees in the } \\
\text { transport industry }\end{array}$ & 0.1541 & $\begin{array}{c}- \\
0.0306\end{array}$ & 0.9532 & \\
\hline $\begin{array}{l}\text { The second industry } \\
\text { added value }\end{array}$ & $\begin{array}{c}- \\
0.1904\end{array}$ & 0.9676 & 0.0248 & \multirow{3}{*}{$\begin{array}{c}\text { Current situation of } \\
\text { railway passenger } \\
\text { transport Factor }\end{array}$} \\
\hline $\begin{array}{c}\text { Tertiary industry } \\
\text { added value }\end{array}$ & 0.2056 & 0.9533 & 0.0006 & \\
\hline $\begin{array}{c}\text { Railway Passenger } \\
\text { Turnover }\end{array}$ & $\begin{array}{c}- \\
0.5403\end{array}$ & 0.6442 & 0.4334 & \\
\hline
\end{tabular}

According to the factor model, the following three common factors can be derived:

Per capita GDP (x1), consumption per capita (x2), and average wage of employees in urban units (x7) have a larger factor load on the first common factor F1. These indicators reflect the social conditions in the eastern region. The status of economic development and the level of household consumption, therefore, the F1 is named 'Economic Development and Household Consumption Factor."

The second industry added value (x5), the tertiary industry added value (x6) and the railway passenger traffic volume (x8) have a larger load on the second common factor. As the railway passenger transport is a part of the tertiary industry, the F2 is named "Industrial Development Factor."

The operating mileage (x3) and the number of transported employees (x4) have a large factor load on the third common factor, and they both reflect the status of railway development. Therefore, it is named as "Current situation of railway passenger transport Factor”.

\section{Score calculation}

According to the factor normalization score coefficient, the score function of three common factors is obtained:

\section{TABLE III. VARIANCE EXPLAINED BY EACH FACTOR}

\begin{tabular}{|c|c|c|}
\hline Factor1 & Factor2 & Factor3 \\
\hline 3.5189946 & 2.4517423 & 1.4938688 \\
\hline
\end{tabular}

We use the proportion of the variance contribution rate of each common factor to the total variance contribution rate of the three publicity factors as the weight to construct a comprehensive evaluation function.

$$
\mathrm{F}=0.44 \mathrm{~F}_{1}+0.306 \mathrm{~F}_{2}+0.187 \mathrm{~F}_{3}
$$

Finally, the comprehensive factor scores and rankings of the demand for railway passenger transport in the eastern region are obtained. The comprehensive evaluation results are shown in Table III.

TABLE IV. FACTOR SCORE TABLE

\begin{tabular}{|c|c|c|c|c|c|}
\hline \multirow{2}{*}{ Region } & F1 & F2 & F3 & \multicolumn{2}{|c|}{ Score F } \\
\cline { 2 - 6 } & Score & Score & Score & Score & Rank \\
\hline Beijing & 1.6036 & -0.6638 & 1.0373 & 0.6964 & 1 \\
\hline Shanghai & 1.6237 & -0.3755 & -0.237 & 0.5552 & 2 \\
\hline Jiangsu & 0.1966 & 1.4421 & -0.757 & 0.3862 & 3 \\
\hline Guangdong & -0.092 & 1.6312 & -0.5909 & 0.3482 & 4 \\
\hline Shandong & -0.465 & 0.8862 & 0.6784 & 0.1935 & 5 \\
\hline Liaoning & -0.442 & -0.3474 & 1.9529 & 0.0643 & 6 \\
\hline Zhejiang & 0.0746 & 0.4211 & -0.5884 & 0.0517 & 7 \\
\hline Tianjin & 0.6860 & -0.6815 & -0.6271 & -0.0240 & 8 \\
\hline Fujian & -0.5442 & -0.6541 & -0.3020 & -0.4961 & 9 \\
\hline Hebei & -1.5114 & -0.0143 & 0.8750 & -0.5058 & 10 \\
\hline Hainan & -1.1299 & -1.6439 & -1.4405 & -1.2696 & 11 \\
\hline
\end{tabular}

\section{CONCLUSION}

Judging from the comprehensive evaluation scores, there is an imbalance in the demand for railway passengers in the eastern region, and also a large difference among different regions. The provinces with upstream passenger demand are Beijing, Shanghai, and Jiangsu, while those in the middle are Guangdong and Shandong. Liaoning, Zhejiang, and Tianjin. Fujian, Hebei, and Hainan are located in the lower reaches

Beijing is at the first place of comprehensive passenger transportation demand, which is mainly attributed to the high level of economic development and the good status of railway construction. As shanghai is the economic center of our country and the center of railway transportation hub, Shanghai ranks second in overall rail passenger demand.

Jiangsu, Guangdong, Shandong, and Zhejiang are all located at a moderate level. These provinces all have high levels of economic development. At the same time, these provinces are dominated by the tertiary industry and the secondary industry. However, terrain also affects economic development .For example, in the south of Zhejiang, there are relatively many mountains. So the scale of railway development is limited. However, because of its high level of economic development, the ranking is moderate. 
Hainan Province is at the final place. Hainan is located in the south of China, and is connected to China's mainland by sea and air. Therefore, the conditions for the development of railway $t$ are poor. At the same time, Hainan attaches great importance to the development of tourism and pays attention to the tertiary industry and the primary industry.

\section{REFERENCES}

[1] Cui Yanping, "Analysis of the External Environment for the Development of Railway Passenger Transport and Passenger Demand," Chinese Railway, vol.2, pp. 9-13, 2014.
[2] Jia Lizhai, Li Weidong, "Analysis of Demand for High Speed Railway Passenger Transport in China," Value Engineering, vol.19, 2010, pp.103-104.

[3] Tian Fei, "Optimizing the Forecast of Passenger Demand for Intercity Railway,” Railway Construction Technology, vol. 5, 2012, pp. 77-85.

[4] Zhang Nian, "Comprehensive Evaluation of Railway Freight Transport Demand in Central and Western Regions Based on Factor Analysis," Logistics Technology, 2010.

[5] Wang Xuemin, "Applied Multivariate Analysis," Shanghai: Shanghai University of Finance and Economics Press, 2014

[6] Li Qiuxia,Wang Zhanzhong,"Research on Performance Evaluation of Highway Transportation Based on Factor Analysis,” Highway Traffic Technology. vol.2, 2009. 